\title{
EFFECT OF SALINITY ON SOIL RESPIRATION AND NITROGEN DYNAMICS
}

\author{
WPEYW ZASOLENIA NA RESPIRACJE GLEBY I DYNAMIKE AZOTU
}

\begin{abstract}
A facility of BaPS (Barometric Process Separation) and indoor incubation experiments were used to determine the effect of soil salinity on soil respiration and nitrogen transformation. The rates of soil respiration, gross nitrification, denitrification, ammonium and nitrate nitrogen concentrations and relevant soil parameters were measured. Results showed that soil respiration and nitrification and denitrification rates were all affected by soil salinity. Furthermore, the effect of soil salinity level on nitrification and denitrification rates had a threshold value $\left(E C_{1: 5}=1.13 \mathrm{dS} / \mathrm{m}\right)$. When soil salinity level was smaller to this threshold value, the rates of nitrification and denitrification increased with soil salinity while they were reduced when soil salinity level was larger than the threshold value. Moreover, the changing law of soil respiration rate with soil salinity was similar with the nitrification and denitrification rates while the variation tendency was opposite. In addition, the transformation form urea to ammonium and nitrate nitrogen was also reduced with the increase of soil salinity and the reduced effect could be expressed by exponential functions.
\end{abstract}

Keywords: BaPS system, soil salinity, nitrification, denitrification, respiration

\section{Introduction}

Greenhouse gas emissions are the main reasons of global warming, which caused extreme weather disasters happened frequently all over the world in the past 10 years $[1,2]$. Previous studies have shown that agricultural-source greenhouse gas emissions account for about $14 \%$ of the global greenhouse gas emissions caused by human activities. Furthermore, the ratio shows an increasing trend and $\mathrm{N}_{2} \mathrm{O}$ (one of the greenhouse gas) released into atmosphere from soil might increase $26 \%$ from 2011 to 2020 [2].

Nitrogen is often the most limiting nutrient for plant growth in many farmlands, as soil available nitrogen greatly impacts farmland primary productivity and plant community structure [3,4]. The second general detailed soil survey of China indicated that nitrogen contents of about $40 \%$ upland fields were below $0.75 \mathrm{~g} \mathrm{~kg}^{-1}$ and nitrogen application accounted for $43.1 \%$ of all the fertilizer application in 2009. However, nitrogen fertilizers also play an important role in agricultural-source greenhouse gas emissions. This is because

\footnotetext{
1 State Key Laboratory of Water Resources and Hydropower Engineering Science, Wuhan University, Wuhan 430072, China

* Corresponding author: wujingweiwhu@gmail.com
} 
nitrogen mineralization, as one of the most important soil nitrogen processes, is the process by which organic nitrogen is converted to plant-available inorganic forms by soil animals and microorganisms with $\mathrm{N}_{2} \mathrm{O}$ released through nitrification and denitrification $[5,6]$. Therefore, the process of soil nitrogen mineralization is closely associated with soil nitrogen-supplying capacities, nitrogen loss and greenhouse gas emissions, which has the important ecological meanings to maintain agricultural ecosystem health and protection $[2,7]$. Meanwhile, soil respiration is another factor of greenhouse gas emissions due to the $\mathrm{CO}_{2}$ released $[8,9]$. In this reason, soil respiration and nitrogen mineralization have become parts of research "hotspots" in environmental and soil fields [10].

According to previous researches, soil microorganism controls soil respiration and nitrogen mineralization [10]. Silva et al found that microbial and actinomycete populations were positively correlated with gross mineralization and ammonium consumption rates [11]. Muller et al used barometric process separation (BaPS) techniques to indicate that soil microorganism affected soil respiration [12]. Additionally, soil respiration and nitrogen mineralization are also influenced by many environmental factors including soil hydrology [7, 13], soil texture [14], and soil aggregate. Moreover, it is widely reported that soil temperature can significantly impact microbial species, quantity, and activity which determine these soil processes [15]. Furthermore, salinity is also considered as a stress of soil microorganisms. Rietz and Hayne [16] found that organic matter decomposition was inhibited by increasing salinity which might cause a substantial decline in potentially mineralized nitrogen. However, Khoi et al [17] found that adverse effects of salinity on nitrogen mineralization were short-lived, whereas the rate of nitrogen mineralization recovered in later stages. Therefore, the above contradictory results indicated that further researches should be taken to find out the effects of soil salinity on soil nitrogen mineralization. The objectives of this study were to (i) monitor the variation of inorganic nitrogen $\left(\mathrm{NH}_{4}{ }^{+}-\mathrm{N}\right.$ and $\left.\mathrm{NO}_{3}{ }^{-}-\mathrm{N}\right)$ in soils with different salt and water content; and (ii) determine the effects of soil salinity on soil respiration and nitrogen dynamics.

\section{Materials and methods}

\section{Soil samples}

Soil samples were collected from a horizon $(0-20 \mathrm{~cm})$ of a soil in Red Soil Engineering Research Center, JiangXi province, China $\left(28^{\circ} 34^{\prime} 36.97^{\prime \prime} \mathrm{N}\right.$ and $\left.115^{\circ} 56^{\prime} 16.43^{\prime \prime} \mathrm{E}\right)$. The area has a subtropical humid monsoon climate, and the average temperature is $26.35^{\circ} \mathrm{C}$ in summer and $9.5^{\circ} \mathrm{C}$ in winter with mean annual rainfall of $1650 \mathrm{~mm}$. Samples were thoroughly mixed, air dried, pass through a $2 \mathrm{~mm}$ sieve and stored air-dry at room temperature.

\section{Soil characterization}

Both sieving and hydrometer method were used to analyze soil particles while the sodium hexametaphosphate (AR) was selected as dispersant. According to the soil texture triangle (USDA), the soil samples were classified as silty clay loam (Table 1). Soil $\mathrm{pH}$ and EC were measured in a 1:5 soil: water suspension after $1 \mathrm{~h}$ end-over-end shaking at $25^{\circ} \mathrm{C}$. The water holding capacity (WHC) was measured using a sintered glass funnel connected to a $100 \mathrm{~cm}$ water column. Soil was placed in rings in the sintered glass funnel, thoroughly 
wetted and allowed to drain for $48 \mathrm{~h}$. Dry weight of the soil was determined after oven drying at $105^{\circ} \mathrm{C}$ for $24 \mathrm{~h}$. The organic carbon was analyzed by dichromate oxidation.

Physical and chemical properties of the soils

Table 1

\begin{tabular}{|c|c|c|}
\hline Soil property & Unit & Silty clay loam \\
\hline Clay & {$[\%]$} & 15.80 \\
\hline Silt & {$[\%]$} & 72.40 \\
\hline Sand & {$[\%]$} & 11.80 \\
\hline $\mathrm{EC}_{(1: 5)}$ & {$[\mathrm{dS} / \mathrm{m}]$} & 0.14 \\
\hline $\mathrm{pH}_{(1: 5)}$ soil:water & {$[-]$} & 5.79 \\
\hline Bulk density & {$\left[\mathrm{g} / \mathrm{cm}^{3}\right]$} & 1.40 \\
\hline Water holding capacity & {$\left[\mathrm{g} \cdot \mathrm{g}^{-1} \mathrm{soil}^{-1}\right]$} & 0.28 \\
\hline Organic matter content & {$[\mathrm{g} / \mathrm{kg}]$} & 30.33 \\
\hline
\end{tabular}

\section{Experimental design}

\section{Soil preparation}

Six salt solutions with different EC were prepared using combinations of $1 \mathrm{M} \mathrm{NaCl}$ solutions and distilled water. The EC of the solutions were 2.12, 8.25, 15.59, 26.77, 33.95, $42.73 \mathrm{dS} \mathrm{m}^{-1}$. The experimental soils (approximately $4000 \mathrm{~g}$ ) were placed on six funnels with filter papers and leached 3-4 times with these solutions, respectively. At each leaching event, about $100-120 \mathrm{~cm}^{3}$ of the solution was added to each funnel after which soils were dried at $30-40^{\circ} \mathrm{C}$ in a fan-forced oven for $72 \mathrm{~h}$, mixed thoroughly after drying to break the clods and then analyzed for $E C$. The drying maximized the soil-solution contact. This process was repeated until the desired combination of $E C\left(E C_{1: 5}\right.$ levels of $0.14,0.67,1.13$, $1.83,2.28,2.83 \mathrm{dS} \mathrm{m}^{-1}$ ) were achieved. After adjustment of $E C$, the soils were kept dry at room temperature until the onset of the experiment.

\section{Theory of the Barometric process separation method (BaPS)}

If a net pressure decrease is observed, nitrification in the system is predominant. Therefore, a pressure increase indicates that denitrification is the dominating process. The three microbiological processes can be described by the following reaction equations [18]:

(a) Soil respiration:

$$
\mathrm{CH}_{2} \mathrm{O}+\mathrm{O}_{2, \mathrm{Atm}} \rightarrow \mathrm{CO}_{2, \mathrm{Atm}}+\mathrm{H}_{2} \mathrm{O}
$$

(b) Nitrification:

$$
\mathrm{NH}_{4}^{+}+2 \mathrm{O}_{2, \mathrm{Nit}} \rightarrow \mathrm{NO}_{3}^{-}+\mathrm{H}_{2} \mathrm{O}+2 \mathrm{H}^{+}
$$

(c) Denification:

$$
5 \mathrm{CH}_{2} \mathrm{O}+4 \mathrm{NO}_{3}^{-}+4 \mathrm{H}^{+} \rightarrow 5 \mathrm{CO}_{2, \text { Den }}+7 \mathrm{H}_{2} \mathrm{O}+2 \mathrm{~N}_{2}
$$

$\mathrm{CO}_{2}$ and $\mathrm{O}_{2}$ concentrations (optionally $\mathrm{N}_{2} \mathrm{O}$ concentrations) in the headspace over the soil samples are measured at the same time as the system pressure. By measuring the system pressure changes the total gas balance $\Delta n / \Delta t\left[\mu \mathrm{mol} \mathrm{h}{ }^{-1}\right]$ of the above processes can be determined. Furthermore, by a combination of this gas balance with the $\mathrm{O}_{2}$ and $\mathrm{CO}_{2}$ balance, the rate of the gaseous nitrogen compounds $\mathrm{N}_{\mathrm{X}} \mathrm{O}_{\mathrm{Y}}\left(\mathrm{N}_{2}, \mathrm{~N}_{2} \mathrm{O}, \mathrm{NO}\right)$ contributed by 
denitrification can be determined. Moreover, if the total gas balance of the system, determined by the pressure measurement, is not explainable with the oxygen and $\mathrm{CO}_{2}$ balance, this balance gap must be a result of the gaseous nitrogen compounds formed during denitirfication.

Based on above analysis, the central equation of the BaPS method can be obtained as [19]:

$$
\Delta N_{X} O_{Y}=\Delta n-\triangle O_{2}-\triangle C O_{2}
$$

where $\Delta N_{X} O_{Y}\left[\mathrm{~mol} \mathrm{~s}^{-1}\right]$ stands for the rate of $\mathrm{N}$ gases produced by denitrification, $\Delta n$ [mol s${ }^{-1}$ ] denotes the net rate of total gas production or consumption, while $\Delta O_{2}$ [mol s $\mathrm{s}^{-1}$ ] and $\Delta C \mathrm{O}_{2}\left[\mathrm{~mol} \mathrm{~s}^{-1}\right]$ are the net rates of $\mathrm{O}_{2}$ depletion and $\mathrm{CO}_{2}$ formation, respectively, in the chamber's headspace atmosphere. Therefore, soil respiration and nitrification can be quantified with an inverse balance.

\section{Measurement of soil nitrogen concentration}

$2 \mathrm{M} \mathrm{KCl}$ and saturated $\mathrm{CaSO}_{4}$ were used to extract ammonium and nitrate nitrogen respectively and the ratio between soil and extract was 1:5. Shaking end-over-end for $1 \mathrm{~h}$ filtered and determined nitrogen concentrations by using a Cleverchem 200 auto analyzer (Dechem-Tect Germany). Noted that the filtered samples were stored in a refrigerator at $4^{\circ} \mathrm{C}$ if analysis was to be within 10 days. If there was a longer delay, samples were immediately frozen at $-5^{\circ} \mathrm{C}$ and then defrosted at $4^{\circ} \mathrm{C}$ prior to analysis [14].

\section{Pre-incubation}

For obtaining a relative maximum soil respiration rate and exhausting the effect of water content on soil respiration, we set the initial soil water content about $70 \%$ WHC $\left(18.5 \mathrm{~g} \cdot 100 \mathrm{~g} \mathrm{soil}^{-1}\right)$. These water contents were achieved by adding the required amount of distilled water to soils and mixed fully in sealing bags and put them into a $25^{\circ} \mathrm{C}$ incubator for 14 days [14]. This 14 days pre-incubation was selected on the basis of Betterly et al [20], who found that microbial activity stabilized within 10 days after rewetting air-dry soil. Throughout the pre-incubation period, distilled water was added on a mass basis to maintain the target water content.

\section{Incubations}

Two incubation experiments were done in our study. In the first incubation, we filled fifty-four $100 \mathrm{~cm}^{3}$ soil rings with the pre-incubated soils of six salinity levels according to designed bulk density $\left(1.40 \mathrm{~g} \mathrm{~cm}^{-3}\right)$. After that, we determined the gross nitrification rate, denitrification rate, and soil respiration rate through BaPS technology, in each salinity treatment, we put three rings into the BaPS incubation equipment and we determined three times for each salinity treatment. Before incubation, we syringed $2 \mathrm{~cm}^{3} 100 \mathrm{~g} \mathrm{dm}^{-3}$ urea (AR) solution to each soil ring and we determined the ammonium and nitrate nitrogen concentrations before and $20 \mathrm{~h}$ after incubations.

In the second incubation, we filled ninety $25 \mathrm{~cm}^{3}$ soil rings with the pre-incubated soils of six salinity levels according to designed bulk density $\left(1.40 \mathrm{~g} \mathrm{~cm}^{-3}\right)$. Then we syringed $2 \mathrm{~cm}^{3} 10 \mathrm{~g} \mathrm{dm}^{-3}$ urea (AR) solution to each soil ring and incubate them 10 days under $25^{\circ} \mathrm{C}$. We measured the mass of each soil ring every day during the incubation period and we 
determined the ammonium and nitrate nitrogen concentrations before and 2, 4, 6, 8 and $10 \mathrm{~d}$ after incubations (triplicate repeats).

\section{Statistical analysis}

The data were analyzed using SPSS (version 18.0). Gross nitrification, denification, soil respiration, nitrogen concentrations and water content data were subjected to analysis of variance (ANOVA) and least significant difference (LSD) test was used to determine significant differences $(p<0.05)$ of treatments.

\section{Results}

\section{Gross nitrification, denitrification, and soil respiration}

Analysis of variance showed that gross nitrification rate, denitrification rate, and soil respiration rate varied significantly across soil salinity levels (Table 2). The rate of gross nitrification and denitrification decreased 86.31 and $83.43 \%$ respectively when the $E C_{1: 5}$ increased from 0.67 to $2.28 \mathrm{dS} / \mathrm{m}$. Furthermore, when the $\mathrm{EC}_{1: 5}$ increased to $2.83 \mathrm{ds} / \mathrm{m}$, the gross nitrification rate occurred to be negative and the denitrification rate decreased to 0 . On the contrary, soil respiration rate gradually increased as the soil $\mathrm{EC}_{1: 5}$ increased from 0.67 to $2.83 \mathrm{dS} / \mathrm{m}$ and turned from negative into positive in the threshold of $1.83-2.28 \mathrm{dS} / \mathrm{m}$ (Table 3).

Statistical significance for gross nitrification, denitrification, and soil respiration

\begin{tabular}{|c|c|c|c|}
\hline \multirow{2}{*}{ Source of variation } & Gross nitrification rate & Denitrification rate & Soil respiration rate \\
\cline { 2 - 4 } & $\boldsymbol{P}>\boldsymbol{F}$ & $\boldsymbol{P}>\boldsymbol{F}$ & $\boldsymbol{P}>\boldsymbol{F}$ \\
\hline Salinity $\left(\mathrm{EC}_{1: 5}\right)$ & 0.0001 & 0.0001 & 0.0001 \\
\hline
\end{tabular}

Note: $P$ is the $p$-value and $F$ denotes the F-test.

Table 3

Effects of salinity on gross nitrification, denitrification, and soil respiration

\begin{tabular}{|c|c|c|c|}
\hline \multirow{2}{*}{ Treatment } & Gross nitrification rate & Denitrification rate & Soil respiration rate \\
\cline { 2 - 4 } & {$[\boldsymbol{\mu g} \mathbf{~ N} / \mathbf{k g ~ h}]$} & {$[\boldsymbol{\mu g} \mathbf{~ N} / \mathbf{k g ~ h}]$} & {$[\boldsymbol{\mu g} \mathbf{C} / \mathbf{k g ~ h}]$} \\
\hline Salinity $\left(E C_{1: 5}\right)$ & & & $-3839.13 \mathrm{~d}$ \\
\hline $0.14 \mathrm{dS} \mathrm{m}^{-1}$ & $4339.27 \mathrm{c}$ & $6317.60 \mathrm{c}$ & $-7403.47 \mathrm{f}$ \\
\hline $0.67 \mathrm{dS} \mathrm{m}^{-1}$ & $7390.80 \mathrm{a}$ & $9348.67 \mathrm{a}$ & $-4551.07 \mathrm{e}$ \\
\hline $1.13 \mathrm{dS} \mathrm{m}^{-1}$ & $4585.83 \mathrm{~b}$ & $6617.10 \mathrm{~b}$ & $-1856.97 \mathrm{c}$ \\
\hline $1.83 \mathrm{dS} \mathrm{m}^{-1}$ & $3041.63 \mathrm{~d}$ & $4524.27 \mathrm{~d}$ & $1091.67 \mathrm{~b}$ \\
\hline $2.28 \mathrm{dS} \mathrm{m}^{-1}$ & $1011.77 \mathrm{e}$ & $1549.07 \mathrm{e}$ & $2311.10 \mathrm{a}$ \\
\hline $2.83 \mathrm{dS} \mathrm{m}^{-1}$ & $-25.27 \mathrm{f}$ & $0 \mathrm{f}$ & \\
\hline
\end{tabular}

Note: For each treatment effect, means within a column followed by the same letter are not significantly different at $p<0.05$.

In addition, it could be seen form Figure 1 that all of the gross nitrification rate, denitrification rate and soil respiration rate had a peak value when the soil $E C_{1: 5}$ was $0.67 \mathrm{dS} / \mathrm{m}$. To be more exact, the values of gross nitrification rate and denitrification rate reached highest when the $E C_{1: 5}$ was $0.67 \mathrm{dS} / \mathrm{m}$, these two values were comparable when the $E C_{1: 5}$ were 0.14 and $1.13 \mathrm{dS} / \mathrm{m}$ respectively and when $E C_{1: 5}$ value was more than $1.13 \mathrm{dS} / \mathrm{m}$, 
the rates of gross nitrification and denitrification would be obviously smaller than non-saline conditions $\left(E C_{1: 5}=0.14 \mathrm{dS} / \mathrm{m}\right)$. Furthermore, the changing law of soil respiration rate with $E C_{1: 5}$ was similar with the gross nitrification and denitrification rates while the variation tendency was opposite (Fig. 1).
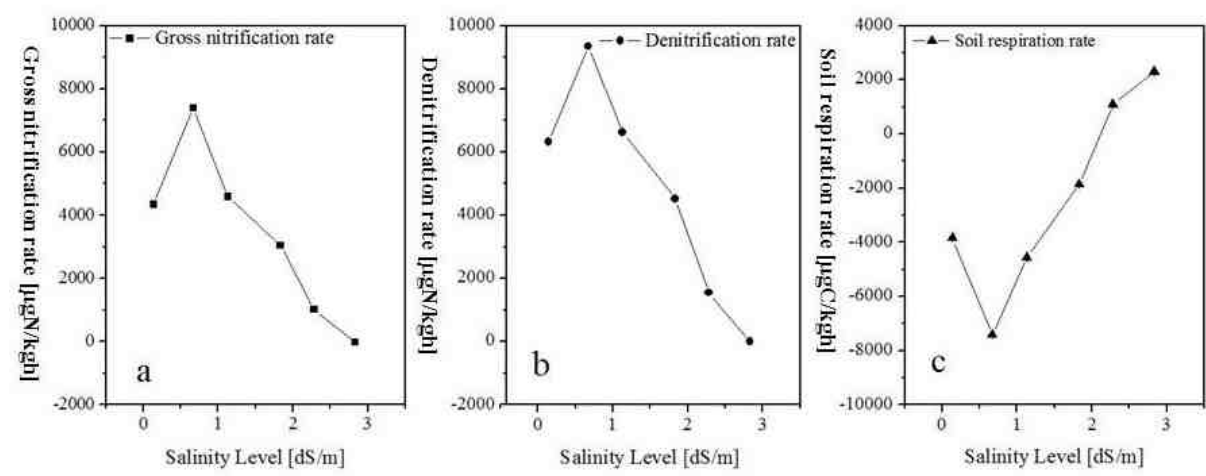

Fig. 1. Effects of salinity on the rates of gross nitrification, denitrification, and soil respiration

\section{Nitrogen concentrations in the first incubation}

In the first incubation experiment, we syringed $2 \mathrm{~cm}^{3} 100 \mathrm{~g} / \mathrm{dm}^{3}$ urea (AR) solution to each treatment. Table 4 indicated that the ammonium and nitrate nitrogen concentrations were significantly affected by soil salinity levels 20 hours after incubation. To be more specific, the ammonium and nitrate nitrogen concentrations decreased 87.37 and $34.41 \%$ when the $E C_{1: 5}$ increased from 0.14 to $2.83 \mathrm{dS} / \mathrm{m}$ (Table 5).

Table 4

Statistical significance for ammonium and nitrate nitrogen concentrations $20 \mathrm{~h}$ after incubation

\begin{tabular}{|c|c|c|}
\hline $\begin{array}{c}\text { Source of } \\
\text { variation }\end{array}$ & Ammonium Nitrogen & $\begin{array}{c}\text { Nitrate } \\
\text { Nitrogen }\end{array}$ \\
\cline { 2 - 3 } & $\boldsymbol{P}>\boldsymbol{F}$ & $\boldsymbol{P}>\boldsymbol{F}$ \\
\hline Salinity $\left(E C_{1: 5}\right)$ & 0.0001 & 0.0001 \\
\hline
\end{tabular}

Note: $P$ is the $p$-value and $F$ denotes the F-test.

Table 5

Effects of salinity on ammonium and nitrate nitrogen concentrations $20 \mathrm{~h}$ after incubation

\begin{tabular}{|c|c|c|}
\hline \multirow{2}{*}{ Treatment } & Ammonium Nitrogen & $\begin{array}{c}\text { Nitrate } \\
\text { Nitrogen }\end{array}$ \\
\cline { 2 - 3 } & {$\left[\mathbf{m g} / \mathbf{d m}^{3}\right]$} & {$\left[\mathbf{m g} / \mathbf{d m}^{\mathbf{3}}\right]$} \\
\hline Salinity $\left(E C_{1: 5}\right)$ & & $0.093 \mathrm{a}$ \\
\hline $0.14 \mathrm{dS} \mathrm{m}^{-1}$ & $101.24 \mathrm{a}$ & $0.071 \mathrm{~cd}$ \\
\hline $0.67 \mathrm{dS} \mathrm{m}^{-1}$ & $45.79 \mathrm{~b}$ & $0.080 \mathrm{~b}$ \\
\hline $1.13 \mathrm{dS} \mathrm{m}^{-1}$ & $42.20 \mathrm{~b}$ & $0.076 \mathrm{bc}$ \\
\hline $1.83 \mathrm{dS} \mathrm{m}^{-1}$ & $24.66 \mathrm{c}$ & $0.062 \mathrm{de}$ \\
\hline $2.28 \mathrm{dS} \mathrm{m}^{-1}$ & $14.49 \mathrm{~d}$ & $0.061 \mathrm{e}$ \\
\hline $2.83 \mathrm{dS} \mathrm{m}^{-1}$ & $12.79 \mathrm{~d}$ & \\
\hline
\end{tabular}

Note: For each treatment effect, means within a column followed by the same letter are not significantly different at $p<0.05$. 
Moreover, Figure 2a-b showed that the ammonium nitrogen concentration $20 \mathrm{~h}$ after incubation generally decreased with the increase of soil salinity level while the change of nitrate nitrogen was fluctuant. However, we could also fit the nitrate nitrogen concentration by exponential function the same as ammonium nitrogen fitting. And the correlation coefficients of ammonium and nitrate nitrogen concentrations (R-square) fitting were 0.9686 and 0.8943 respectively (Fig. 2).
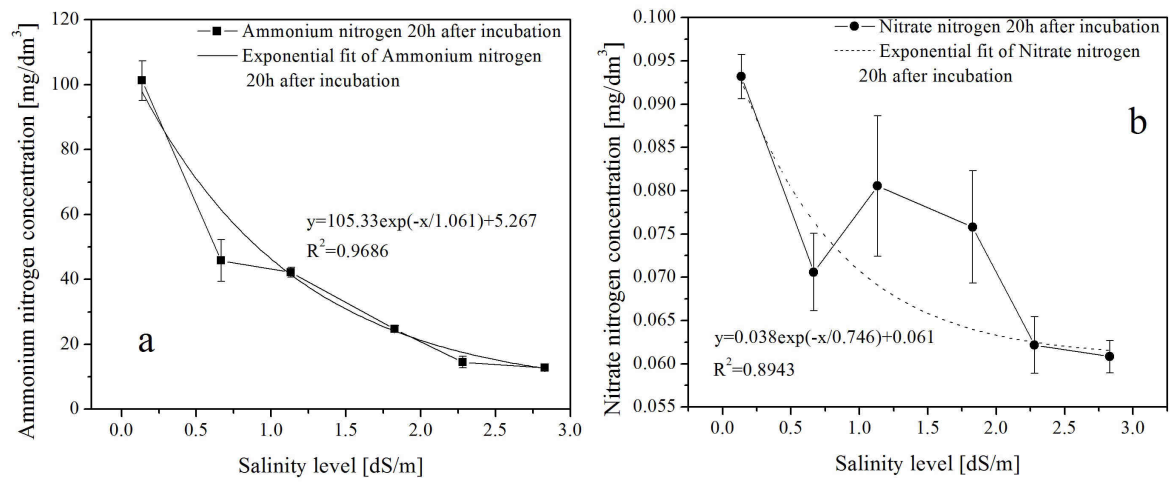

Fig. 2. Effects of salinity on ammonium and nitrate nitrogen concentrations

\section{Water and nitrogen dynamics in the second incubation}

Due to the evaporation during the second incubation experiment, the water content of each treatment decreased with time. More exactly, the mean water content of treatments decreased $92 \%$ from 0 to $10 \mathrm{~d}$ after incubation (Fig. 3). Moreover, Figure 3 also illustrated that soil salinity level could affect evaporation too. To be more specific, the higher soil salinity level, the lower evaporation speed and this effect might be more obvious when the $E C_{1: 5}$ was higher than $1.83 \mathrm{dS} / \mathrm{m}$.

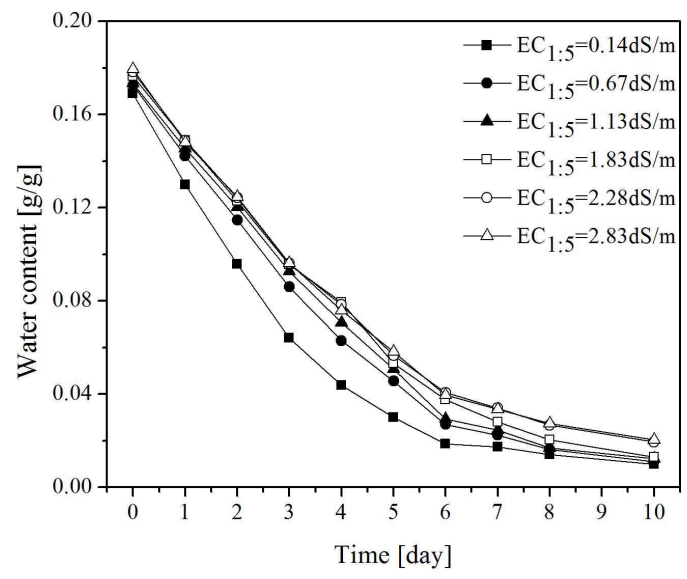

Fig. 3. Changes of soil water content during the period of incubation 
Generally speaking, the ammonium nitrogen concentration increased first and then decreased while the nitrate nitrogen concentration fluctuated during the 10 days incubation period and the peak ammonium nitrogen value occurred about $6 \mathrm{~d}$ after incubation. Similar to the first incubation, both the ammonium and nitrate nitrogen concentrations decreased with the increase of soil salinity level (Fig. 4).
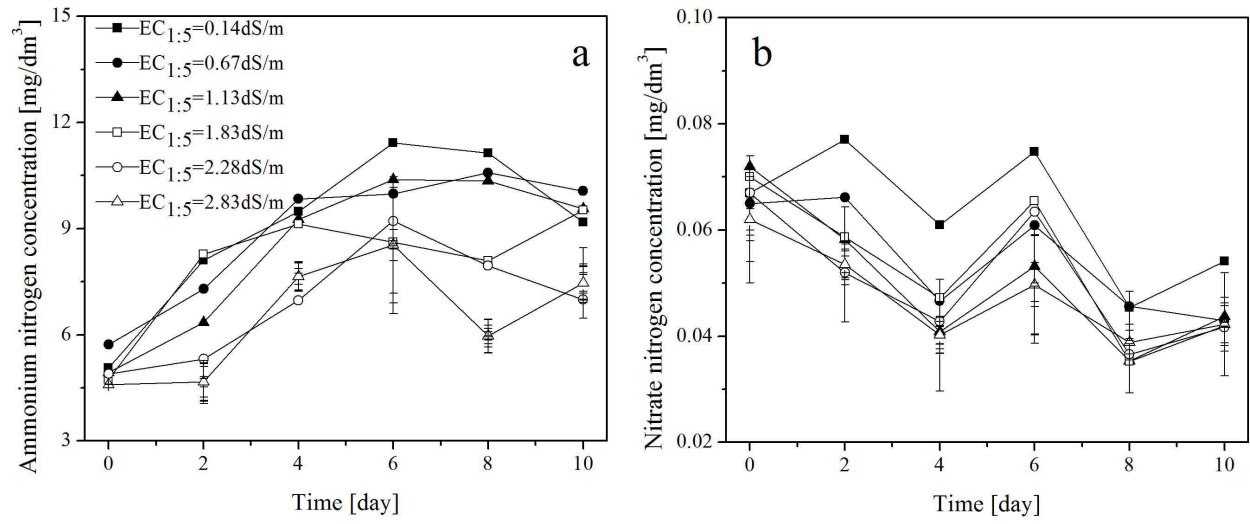

Fig. 4. Changes of soil nitrogen concentrations during the period of incubation

\section{Discussions}

\section{Determination of nitrification, denitrification, and soil respiration by BaPS system}

$\mathrm{BaPS}$ is based on the measuring of the $\mathrm{CO}_{2}, \mathrm{O}_{2}$ and total gas balance of soil samples. In such an isothermal and gas tight system, nitrification, denitrification and soil respiration are the main biological processes responsible for gas pressure changes. Based on the gas balance and inverse balance approach, the rates of nitrification, denitrification, and respiration can be calculated [18,21]. A series of previous investigations showed the good agreement in the result of soil respiration measured by BaPS and gas chromatography [22, 23], and in values of gross nitrification and denitrification rates based on the BaPS system and other methods, such as ${ }^{15} \mathrm{~N}$-pool dilution technique.

However, this technology also has some shortcomings. In this technology, the calculation of gas change $\left(\mathrm{eg} \mathrm{CO}_{2}\right)$ was restricted to the physical dissolution of gas into water using Henry's law. This was feasible because the studied soil's pH was $<4$ and therefore the other two species of the carbonate equilibrium, $\mathrm{HCO}_{3}{ }^{-}$and $\mathrm{CO}_{3}{ }^{2-}$, were negligible [12]. At $\mathrm{pH}$ values $>6$, however, these two species become significant. Therefore, according to Ingwersen's study [19], measurement using BaPS system was believable when the soil $\mathrm{pH}<6$. In our study, the $\mathrm{pH}$ of soil sample was 5.7 and thus we could determine the rates of nitrification, denitrification, and soil respiration by BaPS system.

\section{Effect of salinity on nitrification, denitrification, and soil respiration}

Soil nitrification and denitrification were the main processes of producing $\mathrm{N}_{2} \mathrm{O}$. Furthermore, previous studies have shown that nitrification played a more important role in 
$\mathrm{N}_{2} \mathrm{O}$ production, especially in wheat farmland soil, where urea was applied as nitrogen fertilizer [23]. In our study, soil salinity level significantly affected the rates of nitrification and denitrification. Therefore, soil salinity level could affect the $\mathrm{N}_{2} \mathrm{O}$ production indirectly. We found the rates of nitrification and denitrification occurred peak values when $E C_{1: 5}$ was $0.67 \mathrm{dS} / \mathrm{m}$, then decreased with the increase of $\mathrm{EC}_{1: 5}$, when the value of $E C_{1: 5}$ was more than $1.13 \mathrm{dS} / \mathrm{m}$, the nitrification and denitrification rates became lower than the initial condition $\left(E C_{1: 5}=0.14 \mathrm{dS} / \mathrm{m}\right)$. According to this phenomenon, we assumed that the effect of soil salinity level on nitrification and denitrification rates had a threshold value $\left(E C_{1: 5}=1.13 \mathrm{dS} / \mathrm{m}\right)$. To be more exact, when soil salinity level was smaller to this threshold value, the nitrification and denitrification were promoted by soil salinity while they were reduced when soil salinity level was larger than the threshold value. This assumption was similar with the results of the effect of soil salinity level on soil microorganism activity.

Soil respiration was a main way of producing $\mathrm{CO}_{2}$, which was another greenhouse gas. Previous studies found soil respiration was generally directly related to temperature, but responses were ameliorated with decrease in soil moisture [24]. Moreover, in our study, the soil respiration was also affected by soil salinity and it decreased first and then increased with the increase of soil salinity. The decrease in respiration with increasing salinity could be explained by the low osmotic potential $[14,25]$. The low osmotic potential induced by high salinity might reduce microbial activity [26]. However, salinity could also increase the concentration of dissolved organic matter which might promote the soil respiration and this might be the reason of soil respiration increasing in our incubation.

\section{Effects of salinity on nitrogen dynamics}

In the first incubation, we found both ammonium and nitrate nitrogen concentrations decreased with soil salinity and the change rules could be fitted by exponential functions. Therefore, urea transformation decreased with the increasing salinities. For one thing, excessive salts had adverse effects on soil physical and chemical properties and mineralization process [27]; for another, under the high-salinity condition, there would be a shift in microbial population structure, as microbes have adapted to the local high salinity due to long-term acclimatization [28].

In addition, in the first incubation, the effect of salinity on ammonium nitrogen was more obvious than nitrate nitrogen. This was because urea was not transformed into nitrate nitrogen fully. Studies indicated that the proportion of urea transforming into ammonium is $28.9 \%$ in $3-7 \mathrm{~h}$ after urea applied to soil and $63.85-76.50 \%$ in $24 \mathrm{~h}$ while the significant accumulation of nitrate nitrogen occurred about $96 \mathrm{~h}$ after urea was applied $[29,30]$.

The effect of salinity on nitrogen dynamics was consistent in both two incubations. However, in the second incubation, the change of nitrogen with time was fluctuant in each salinity treatment. This phenomenon might be due to the change of soil water content. In our experiment, we found soil salinity could also affect the evaporation and thus affect soil water content; meanwhile, soil water content also varied with time in each treatment. For one thing, soil water content could affect soil nitrogen dynamics independently, greater soil moisture changed, the higher soil nitrogen mineralization rate did [10]. For another, the interaction of soil water content and salinity could make the change of soil nitrogen dynamics more complexly [17]. Therefore, further research need to focus on the coupling interaction of water and salinity which affect soil nitrogen dynamics. 


\section{Conclusions}

Soil respiration and nitrification and denitrification rates were all affected by soil salinity. The effect of soil salinity level on nitrification and denitrification rates had a threshold value $\left(E C_{1: 5}=1.13 \mathrm{dS} / \mathrm{m}\right)$. When soil salinity level was smaller to this threshold value, the nitrification and denitrification were promoted by soil salinity while they were reduced when soil salinity level was larger than the threshold value. Furthermore, the changing law of soil respiration rate with soil salinity was similar with the nitrification and denitrification rates while the variation tendency was opposite. In addition, the transformation form urea to ammonium and nitrate nitrogen was also reduced with the increase of soil salinity and the reduced effect could be expressed by exponential functions. However, the change of urea transformation varied from time was not very clear in our experiment due to the interaction of soil water content and salinity affected nitrogen dynamics and further studies should be focus on this point.

\section{Acknowledgements}

This work was made possible with support provided by the National "Twelfth Five-Year" Plan for Science \& Technology Support Program (Technology integration of agricultural water saving. No.2011BAD25B07), the State Natural Science Fund (Soil salinization prediction of Irrigation District based on data assimilation. No.51279142) and "the Fundamental Research Fund for the Central Universities" of the Ministry of Science and Technology, China. No.2012206020206.

\section{References}

[1] Troy SM, Lawlor PG, O' Flynn CJ, Healy MG. Impact of biochar addition to soil on greenhouse gas emissions following pig manure application. Soil Biol Biochem. 2013;60:173-181. DOI: 10.1016/j.soilbio.2013.01.019.

[2] Lompo DJP, Sangare SAK, Compaore E, Sedogo MP, Predotova M, Schlecht E, Buerkert A. Gaseous emissions of nitrogen and carbon from urban vegetable gardens in Bobo-Dioulasso, Burkina Faso. J of Plant Nutrit and Soil Sci. 2012;175(6):846-853. DOI: 10.1002/jpln.201200012.

[3] Moseman-Valtierra SM, Armaiz-Nolla K, Levin LA. Wetland response to sedimentation and nitrogen loading: diversification and inhibition of nitrogen-fixing microbes. Ecol Appl. 2010;20(6):1556-1568. DOI: 10.1890/08-1881.1.

[4] Zeng, WZ, Xu C, Wu JW, Huang JS. Soil salt leaching under different irrigation regimes: HYDRUS-1D modelling and analysis. J of Arid Land. 2013. DOI: 10.1007/s40333-013-0176-9.

[5] Bono A, Alvarez R. Nitrogen mineralization in a coarse soil of the semi-arid Pampas of Argentina. Arch of Agron and Soil Sci. 2013;59(2):259-272. DOI: 10.1080/03650340.2011.625413.

[6] Antil RS, Sharma T, Inubushi K. Laboratory and greenhouse assessment of plant-available N in organic materials. Arch of Agron and Soil Sci. 2013;59(3):411-422. DOI: 10.1080/03650340.2011.636355.

[7] Borken W, Matzner E. Reappraisal of drying and wetting effects on $\mathrm{C}$ and $\mathrm{N}$ mineralization and fluxes in soils. Global Change Biol. 2009;15(4):808-824. DOI: 10.1111/j.1365-2486.2008.01681.x.

[8] Lai LM, Zhao XC, Jiang LH, Wang YJ, Luo LG, Zheng YR, et al. Soil respiration in different agricultural and natural ecosystems in an arid region. Plos One. 2012;7(10):1-9. DOI: e4801110.1371/journal.pone.0048011.

[9] Han GX, Yu JB, Li HB, Yang LQ, Wang GM, Mao PL, et al. Winter soil respiration from different vegetation patches in the Yellow River Delta, China. Environ Manage. 2012;50(1):39-49. DOI: 10.1007/s00267-012-9869-7.

[10] Bai JH, Gao HF, Xiao R, Wang JJ, Huang C. A review of soil nitrogen mineralization as affected by water and salt in coastal wetlands: issues and methods. Clean-Soil Air Water. 2012;40(10):1099-1105. DOI: 10.1002/clen.201200055. 
[11] Silva RG, Jorgensen EE, Holub SM, Gonsoulin ME. Relationships between culturable soil microbial populations and gross nitrogen transformation processes in a clay loam soil across ecosystems. Nutr Cycl Agroecos. 2005;71(3):259-270. DOI: 10.1007/s10705-004-6378-y.

[12] Muller C, Abbasi MK, Kammann C, Clough TJ, Sherlock RR, Stevens RJ, Jager HJ. Soil respiratory quotient determined via barometric process separation combined with nitrogen-15 labeling. Soil Sci Soc Am J. 2004;68(5):1610-1615.

[13] Mikha MM, Rice CW, Milliken GA. Carbon and nitrogen mineralization as affected by drying and wetting cycles. Soil Biol Biochem. 2005;37(2):339-347. DOI: 10.1016/j.soilbio.2004.08.003.

[14] Mavi MS, Marschner P, Chittleborough DJ, Cox JW, Sanderman J. Salinity and sodicity affect soil respiration and dissolved organic matter dynamics differentially in soils varying in texture. Soil Biol Biochem. 2012;45:8-13. DOI: 10.1016/j.soilbio.2011.10.003.

[15] Buragiene S, Sarauskis E, Romaneckas K, Sakalauskas A, Uzupis A, Katkevicius E. Soil temperature and gas $\left(\mathrm{CO}_{2}\right.$ and $\left.\mathrm{O}_{2}\right)$ emissions from soils under different tillage machinery systems. J Food Agric Environ. 2011;9(2):480-485.

[16] Rietz DN, Haynes RJ. Effects of irrigation-induced salinity and sodicity on soil microbial activity. Soil Biol Biochem. 2003;35(6):845-854. DOI: 10.1016/s0038-0717(03)00125-1.

[17] Khoi CM, Guong VT, Merckx R. Predicting the release of mineral nitrogen from hypersaline pond sediments used for brine shrimp Artemia franciscana production in the Mekong Delta. Aquaculture. 2006;257(1-4):221-231 DOI: 10.1016/j.aquaculture.2006.02.075.

[18] Ingwersen J, Butterbach-Bahl K, Gasche R, Richter O, Papen H. Barometric process separation: New method for quantifying nitrification, denitrification, and nitrous oxide sources in soils. Soil Sci Soc Am J. 1999;63;117-128.

[19] Ingwersen J, Schwarz U, Stange CF, Ju X, Streck T. Shortcomings in the commercialized barometric process separation measuring system. Soil Biol Biochem. 2008;72(1):135-142. DOI: 10.2136/sssaj2007.0092.

[20] Butterly CR, Marschner P, McNeill AM, Baldock JA. Rewetting $\mathrm{CO}_{2}$ pulses in Australian agricultural soils and the influence of soil properties. Biol Fert Soils. 2010;46(7):739-753. DOI: 10.1007/s00374-010-0481-9.

[21] Breuer L, Kiese R, Butterbach-Bahl K. Temperature and moisture effects on nitrification rates in tropical rain-forest soils. Soil Sci Soc Am J. 2002;66:834-844.

[22] Muhr J, Franke J, Borken W. Drying-rewetting events reduce C and N losses from a Norway spruce forest floor. Soil Biol Biochem. 2010;42(8):1303-1312. DOI: 10.1016/j.soilbio.2010.03.024.

[23] Chen ST, Huang Y. Determination of respiration, gross nitrification and denitrification in soil profile using BaPS system. J Environ Sci-China. 2006;18(5):937-943. DOI: 10.1016/s1001-0742(06)60018-1.

[24] Conant RT, Dalla-Betta P, Klopatek CC, Klopatek JM. Controls on soil respiration in semiarid soils. Soil Biol and Biochem. 2004;36(6):945-951. DOI: 10.1016/j.soilbio.2004.02.013.

[25] Chowdhury N, Marschner P, Burns RG. Soil microbial activity and community composition: Impact of changes in matric and osmotic potential. Soil Biol Biochem. 2011;43(6):1229-1236. DOI: 10.1016/j.soilbio.2011.02.012.

[26] Wichern J, Wichern F, Joergensen RG. Impact of salinity on soil microbial communities and the decomposition of maize in acidic soils. Geoderma. 2006;137(1-2):100-108. DOI: 10.1016/j.geoderma.2006.08.001.

[27] Rousk J, Elyaagubi FK, Jones DL, Godbold DL. Bacterial salt tolerance is unrelated to soil salinity across an arid agroecosystem salinity gradient. Soil Biol Biochem. 2011;43(9):1881-1887. DOI: 10.1016/j.soilbio.2011.05.007.

[28] Wong VNL, Dalal RC, Greene RSB. Salinity and sodicity effects on respiration and microbial biomass of soil. Biol Fert Soils. 2008;44(7):943-953. DOI: 10.1007/s00374-008-0279-1.

[29] Kufelnicki A, Jaciubek-Rosinska J. Detection of nitrate(no2-) ions produced in disproportionation of nitrogen(ii) oxide in aqueous solution. Ecol Chem Eng S. 2012;19(1):39-46. DOI: 10.2478/v10216-0110004-0.

[30] Weisshaupt P, Naumann A, Pritzkow W, Noll M. Nitrogen uptake of Hypholoma fasciculare and coexisting bacteria. Mycol Progr. 2013;12(2):283-290. DOI: 10.1007/s11557-012-0834-x.

\section{WPLYW ZASOLENIA NA RESPIRACJĘ GLEBY I DYNAMIKE AZOTU}

Abstrakt: Proces BaPS (Ciśnieniowy Proces Separacji) oraz inkubacja pokojowa zostały wykorzystane do określenia wpływu zasolenia gleby na jej oddychanie i transformację azotu. Mierzono szybkości: respiracji gleby, 
całkowitej nitryfikacji i denitryfikacji, a także stężenie azotu amonowego i azotanowego oraz wartości odpowiednich parametrów gleby. Wyniki wykazały, że respiracja glebowa oraz szybkości nitryfikacji i denitryfikacji były uzależnione od zasolenia gleby. Ponadto stwierdzono, że wpływ poziomu zasolenia gleby na szybkość nitryfikacji i denitryfikacji miał wartość progową $\left(E C_{1: 5}=1,13 \mathrm{dS} / \mathrm{m}\right)$. Gdy poziom zasolenia gleby był mniejszy od tej wartości progowej, szybkości nitryfikacji i denitryfikacji rosły wraz ze wzrostem zasolenia gleby. Jeżeli zasolenie gleby był większe od progowego, to szybkości te malały. Co więcej, zmiany charakteru zależności szybkości respiracji gleby od jej zasolenia były porównywalne z szybkością nitryfikacji i denitryfikacji, podczas gdy tendencja zmian była odwrotna. Ponadto, transformacja mocznika do amoniaku i azotu azotanowego również zmniejszała się przy wzroście zasolenia gleby, a efekt takiego zmniejszania może być wyrażony funkcją wykładniczą.

Słowa kluczowe: układy BaPS, zasolenie gleby, nitryfikacja, denitryfikacja, respiracja 